\title{
PENGARUH VALUE ORIENTATION DAN PERSONALITY TERHADAP NEW ENVIRONMENTAL PARADIGM SISWA
}

\author{
Ervina Dwi Puspita ${ }^{1}$, I Made Putrawan², Mieke Miarsyah ${ }^{3}$ \\ ${ }^{1}$ Student of Biology Education Departement of State University of Jakarta \\ ${ }^{2}$ Environmental Education Departement of State University of Jakarta \\ ${ }^{3}$ Biology Education Departement of State University of Jakarta
}

Email: ervinapuspita03@gmail.com, putrawan.imade@yahoo.com,mmiarsyah@unj.ac.id

\begin{abstract}
The development of paradigm from anthropocentric to new environmental paradigm is necessary. Every student need to have that new paradigm to protect the environment. Students new environmental paradigm can be affected by several factors such as value orientation and personality. This study aimed to determine the effect of value orientation and personality toward student's new environmental paradigm. This study was hold in a first term of 2019/2020 school year at SMA Negeri 4 Kota Bekasi. The method of this research was the survey with quantitative-causal causal approach and path analysis. The sample consisted of 95 students from XI MIPA which selected randomly. The results of study, there is direct effect between value orientation towards new environmental paradigm and personality; personality has direct effect towards new environmental paradigm and a good mediator between of value orientation and new environmental paradigm.
\end{abstract}

Key words : student, value orientation, personality, new environmental paradigm, path analysis. 


\section{PENDAHULUAN}

Keadaan lingkungan semakin berada pada kondisi kritis. Peralihan fungsi lahan, kebakaran hutan, polusi, penebangan ilegal, dan perburuan liar merupakan fenomena menyedihkan yang terjadi pada lingkungan. Salah satu hal yang sedang menjadi perhatian dunia, terutama oleh ilmuwan sains yaitu perubahan iklim. Para ilmuwan sains, sudah dalam tahap mendesak para pemimpin dunia untuk mempercepat upaya mengatasi perubahan iklim (University of East Anglia, 2019). Bahkan, laman surat kabar inggris yaitu The Guardian menyebutkan perubahan iklim bukan lagi 'perubahan' namun 'krisis' (O’Neill, 2019).

Faktor yang menyebabkan lingkungan dalam kondisi yang krisis ialah aktivitas manusia yang semakin kompleks dan terkoneksi antara manusia, ekonomi, dan lingkungan (Matthews \& Keys, 2019). Manusia dipicu perasaan superior daripada makhluk hidup lainnya dan berhak untuk bebas mengeksploitasi alam. Kejadian tersebut diduga bersumber dari kesalahan cara pandang manusia mengenai dirinya terhadap alam.

Perkembangan cara pandang atau paradigma, diawali oleh dominance social paradigm, suatu paradigma yang anti lingkungan. Fakta yang ada, sumber daya yang tersedia di lingkungan terbatas namun kondisi lingkungan semakin lama semakin memprihatinkan. Pirages dan Ehrlich melihat permasalahan lingkungan sebagai akibat dari dominance social paradigm, yang ditandai oleh antroposentrisme, target pertumbuhan ke bidang ekonomi, dan penemuan teknologi (Bernstein \& Szuster, 2019).

Menurut Sastrawijaya, hubungan timbal balik dimiliki antara manusia dan lingkungannya, yang mana keduanya saling mempengaruhi satu sama lain (Sigit, Ernawati, \& Qibtiah, 2017). Dunlap dan Catton menyebutkan perlu adanya pergeseran paradigma dari yang beraliran antroposentrisme (manusia sebagai pusat penentu alam) ke arah paradigma yang mengacu pada lingkungan, yang dikenal sebagai new environmental paradigm (Mehta \& Ouellet, 1995). Paradigma yang akan mempertimbangkan lingkungan dalam bertindak maupun mengambil keputusan. 
Thomas kuhn berpendapat new environmental paradigm merupakan suatu cara pandang atau nilai-nilai masyarakat yang dipercayai dapat memecahkan suatu masalah ilmiah di lingkungan (Kaan, Putrawan, \& Miarsyah, 2019; Putrawan, 2017). New environmental paradigm membantu masyarakat dalam membentuk sikap dan perilaku pro-lingkungan (Putrawan, 2015, 2019; Thomson, 2013). Paradigma yang memahami bahwa manusia hidup di alam ini tidak menjadikan diri manusia tersebut superior terhadap lingkungan (Natasia, Azrai, \& Ernawati, 2015). Paradigma yang mencerminkan bahwa manusia tidak berhak mengeksploitasi alam .

New environmental paradigm perlu dimiliki oleh generasi muda yaitu siswa untuk menjadi masyarakat yang peduli akan lingkungan. Dunlap percaya bahwa pendidikan lingkungan yang didapatkan baik melalui pendidikan formal maupun informal dari tingkat dasar hingga perguruan tinggi akan terus membantu menanamkan new environmental paradigm di antara generasi muda (Dunlap, 2008). Upaya membangun new environmental paradigm dapat melalui proses pembelajaran membandingkan dan melihat implikasi kondisi fisik lingkungan dan kualitas hidup manusia dan spesies lain dari setiap perkembangan paradigma. Sebagai contoh, penggunaan skenario berdasarkan peristiwa aktual atau simulasi dalam penggunaan teknologi energi baru (Arcury, Johnson, \& Scollay, 1986).

New environmental paradigm seseorang dapat dilihat berdasarkan value orientation yang dimiliki. Seperti pada conceptual of research model Hypothesis menurut Tai-Yi Yu dan Tai-Kuei Yu berikut. 

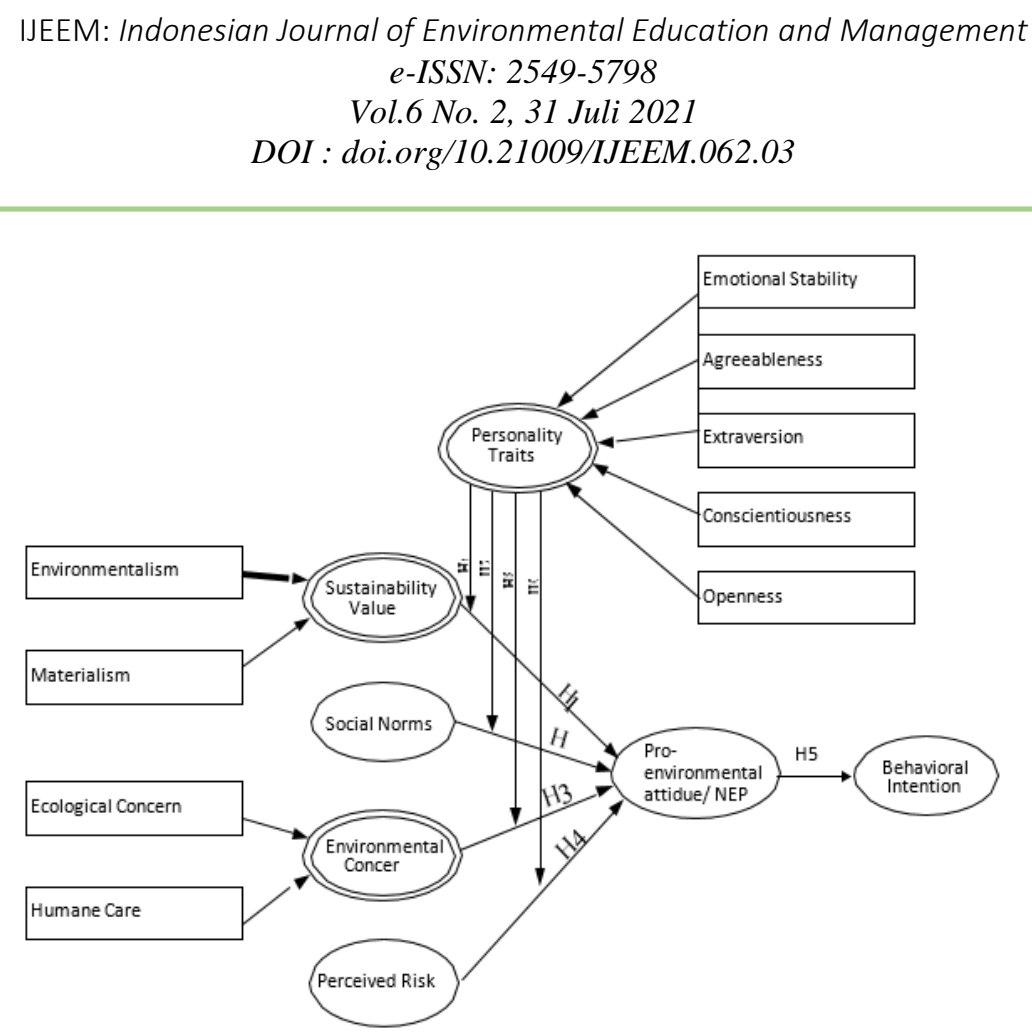

Gambar 1. Conceptual of research model Hypothesis

Value orientation bermakna lebih dalam dan lebih stabil daripada sikap, mewakili keharusan, dan bahkan penentu sikap (Axelrod, 1994). Value orientation adalah keyakinan seseorang yang diwujudkan dengan tingkah laku dalam mencapai tujuan yang diinginkan, dan dijadikan standar atau prinsip diri (Malisi \& Nadiroh, 2017).

Menurut Stern dan Dietz, value orientation dapat mendorong seseorang untuk aktif berusaha mencari informasi yang tersedia tentang nilai atau fungsi dari suatu objek (Han \& Lee, 2016). Value orientation didefinisikan juga sebagai kecenderungan seseorang terhadap tujuan yang berkaitan dengan kepercayaan yang dimiliki individu (Dahriyanto, Rahmawati, \& Muhammad, 2018).

Value orientation pun mengacu pada pandangan ekologis yang didasari oleh tiga dimensi, seperti biospheric, altruistic, dan egoistic. Dimensi biospheric cenderung mendasarkan keputusan terkait lingkungan dari biaya dan manfaat yang dirasakan untuk ekosistem dan biosfer secara keseluruhan (de Groot \& Steg, 2009). Kecenderungan dimensi altruistic diwujudkan dalam respon terhadap norma-norma yang dipercaya bahwa sesuatu kondisi memiliki konsekuensi bagi orang lain (Stern, 2000). Sedangkan dimensi egoistic secara khusus mempertimbangkan biaya dan keuntungan terkait lingkungan untuk pribadi (de Groot \& Steg, 2009).

Selain itu, karakteristik seseorang yang terbentuk selama hidup dalam berinteraksi dengan manusia maupun lingkungan memiliki pengaruh terhadap 
pembentukan new environmental paradigm. Hal ini dapat dilihat juga pada gambar 1, karakteristik yang dimaksud ialah Personality. McShane dan Glinow menyatakan bahwa personality adalah karakteristik seseorang sebagai hasil dari pola pikir, emosi, dan perilaku bersamaan dengan proses psikologis yang dialami (McShane \& Glinow, 2010). Karakteristik personality menggambarkan pola berpikir, perasaan dan tindakan manusia secara spesifik dalam merespon situasi yang dialami (Wright et al., 2005). Karakteristik personality dapat disebut sebagai traits.

Kata Traits merujuk pada perilaku atau emosi seseorang yang konsisten diberbagai situasi. Misalnya, seseorang yang konsisten bertindak dengan teliti, maka dikatakan seseorang tersebut "teliti". Traits sesuatu hal yang implisit, tidak perlu semuanya dijelaskan bila sudah menggunakan istilah traits untuk menggambarkan seseorang (Cervone \& Pervin, 2010). Berdasarkan Jawad dan kawan-kawannya, traits seseorang dapat dipahami sebagai penggambaran seseorang berdasarkan faktor-faktor psikologis (Daikoban, Putrawan, \& S, 2019).

Personality memiliki lima dimensi yang dikenal sebagai big five personality (Putrawan, 2018). Lima dimensinya antara lain openness to the experiences, conscientiousness, extraversion, agreeableness, dan neuroticism ( $\mathrm{Yu} \& \mathrm{Yu}, 2017$ ). Openness to the experiences, dimensi yang ditunjukkan dengan kesediaan seseorang mengalami perubahan, dan hal-hal baru dalam hidup. Conscientiousness merujuk pada tanggung jawab mencakup ketekunan, kredibilitas dan kepatuhan (Abdullah \& Marican, 2016). Extraversion menggambarkan kepribadian yang suka bersosialisasi dan mudah berteman dengan orang lain. Agreeableness lebih cenderung kepada kooperatif, sabar dan toleran. Neuroticism, kecenderungan seseorang dalam mempertahankan stabilitas emosi untuk mengatasi ketegangan apapun (Leephaijaroen, 2016).

Berdasarkan uraian di atas, maka rumusan masalah pada penelitian ini adalah: (1) apakah value orientation berpengaruh langsung terhadap new environmental paradigm siswa?; (2) apakah personality berpengaruh langsung terhadap new environmental paradigm siswa?; (3) apakah value orientation berpengaruh langsung terhadap personality siswa?; dan (4) apakah value orientation berpengaruh tidak langsung terhadap new environmental paradigm melalui personality siswa?. 
Penelitian ini bertujuan untuk mengetahui pengaruh value orientation dan personality terhadap new environmental paradigm yang dimiliki siswa.

\section{METODOLOGI}

Penelitian dilakukan di SMA Negeri 4 Kota Bekasi pada tahun ajaran 2019/2020. Jenis penelitian kuantitatif dengan metode survei yang bersifat kausal dan dianalisis dengan analisis jalur. Jumlah sampel 95 siswa kelas XI SMA yang terpilih secara acak. Terdapat tiga instrumen yang digunakan untuk mengukur new environmental paradigm $\left(\mathrm{X}_{3}\right)$, value orientation $\left(\mathrm{X}_{1}\right)$, dan, personality $\left(\mathrm{X}_{2}\right)$. Masing-masing koefisien reliabilitas sebesar, new environmental paradigm $=0.691$, value orientation $=0.809$, dan personality $=0.864$.

Model dari penelitian digambarkan sebagai berikut:

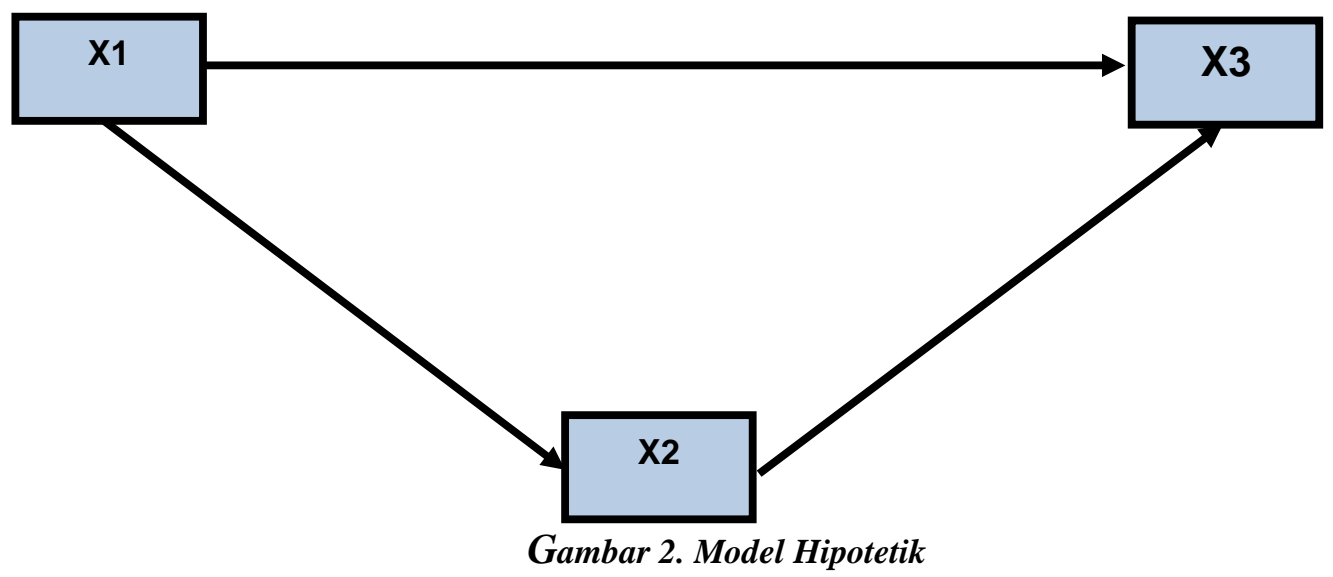

\section{HASIL DAN PEMBAHASAN}

Berdasarkan hasil uji signifikansi dan linearitas value orientation $\left(\mathrm{X}_{1}\right)$ terhadap new environmental paradigm $\left(\mathrm{X}_{3}\right)$, diperoleh konstanta regresi a $=74.610$ dan koefisien regresi $b=0.417$. Dengan demikian menghasilkan persamaan regresi sederhana $\hat{\mathrm{X}}_{3}=74.610+0.417 \mathrm{X}_{1}$. Untuk mengetahui pengaruh langsung antar variabel maka dilakukan perhitungan koefisien jalur dengan bantuan aplikasi SPSS ver. 20. Hasil perhitungan dapat dilihat pada tabel 1 berikut: 
IJEEM: Indonesian Journal of Environmental Education and Management e-ISSN: 2549-5798

Vol.6 No. 2, 31 Juli 2021

DOI : doi.org/10.21009/IJEEM.062.03

Tabel 1. Koefisien Jalur Value orientation $\left(X_{1}\right)$ terhadap New environmental paradigm $\left(X_{3}\right)$

\begin{tabular}{|c|c|c|c|c|c|c|c|c|c|}
\hline \multirow[t]{2}{*}{ Model } & \multicolumn{2}{|c|}{$\begin{array}{c}\text { Unstandardized } \\
\text { Coefficients } \\
\end{array}$} & \multirow{2}{*}{$\begin{array}{c}\begin{array}{c}\text { Standardized } \\
\text { Coefficients }\end{array} \\
\text { Beta }\end{array}$} & \multirow[t]{2}{*}{$\mathrm{t}$} & \multicolumn{2}{|c|}{ t table } & \multicolumn{3}{|c|}{ Correlations } \\
\hline & B & Std. Error & & & 0.05 & 0.01 & $\begin{array}{l}\text { Zero- } \\
\text { order }\end{array}$ & Partial & Part \\
\hline \multirow{2}{*}{$\begin{array}{ll}\text { (Constant) } \\
\text { VO }\end{array}$} & 74.610 & 9.475 & & 7.874 & & & & & \\
\hline & .417 & .080 & .473 & $5.177 * *$ & 1.985 & 2.629 & .473 & .473 & .473 \\
\hline
\end{tabular}

Hasil perhitungan phi31 berdasarkan tabel 1 sebesar 0.473 dengan $t_{\text {hitung }}=5.177$ lebih besar dari $\mathrm{t}_{\text {tabel }}(0.05 ; 93)=1.985$ yang artinya koefisien jalur $\mathrm{X}_{1}$ terhadap $\mathrm{X}_{3}$ signifikan pada $\alpha=0.05$. Dengan demikian terdapat pengaruh langsung antara value orientation terhadap new environmental paradigm yang signifikan.

Berdasarkan hasil uji signifikansi dan linearitas personality $\left(\mathrm{X}_{2}\right)$ terhadap new environmental paradigm $\left(\mathrm{X}_{3}\right)$, diperoleh konstanta regresi $\mathrm{a}=102.528$ dan koefisien regresi $b=0.198$. Dengan demikian menghasilkan persamaan regresi sederhana $\hat{\mathrm{X}}_{3}$ $=102.528+0.198 \mathrm{X}_{2}$. Untuk mengetahui pengaruh langsung antar variabel maka dilakukan perhitungan koefisien jalur dengan bantuan aplikasi SPSS ver. 20. Hasil perhitungan dapat dilihat pada tabel 2. berikut:

Tabel 2. Koefisien Jalur Personality $\left(\mathrm{X}_{2}\right)$ terhadap New environmental paradigm $\left(X_{3}\right)$

\begin{tabular}{|c|c|c|c|c|c|c|c|c|c|c|}
\hline \multirow{2}{*}{\multicolumn{2}{|c|}{ Model }} & \multicolumn{2}{|c|}{$\begin{array}{c}\text { Unstandardized } \\
\text { Coefficients }\end{array}$} & \multirow{2}{*}{$\begin{array}{c}\begin{array}{c}\text { Standardized } \\
\text { Coefficients }\end{array} \\
\text { Beta }\end{array}$} & \multirow[t]{2}{*}{$\mathrm{t}$} & \multicolumn{2}{|c|}{$\mathrm{t}$ table } & \multicolumn{3}{|c|}{ Correlations } \\
\hline & & B & Std. Error & & & 0.05 & 0.01 & $\begin{array}{l}\text { Zero- } \\
\text { order }\end{array}$ & Partial & Part \\
\hline \multirow{2}{*}{1} & (Constant) & 102.528 & 6.189 & & 16.566 & & & & & \\
\hline & Personality & .198 & .058 & .334 & $3.417 * *$ & 1.985 & 2.629 & .334 & .334 & .334 \\
\hline
\end{tabular}

a. Endogenous Variable: NEP

$* * p<0.01$

Hasil perhitungan phi 32 berdasarkan tabel 2 sebesar 0.334 dengan $t_{\text {hitung }}=3.417$ lebih besar dari $\mathrm{t}_{\text {tabel }}(0.05 ; 93)=1.985$ yang artinya koefisien jalur $\mathrm{X}_{2}$ terhadap $\mathrm{X}_{3}$ signifikan pada $\alpha=0.05$. Dengan demikian terdapat pengaruh langsung antara personality terhadap new environmental paradigm yang signifikan. 
Berdasarkan hasil uji signifikansi dan linearitas value orientation $\left(\mathrm{X}_{1}\right)$ terhadap personality $\left(\mathrm{X}_{2}\right)$, diperoleh konstanta regresi $\mathrm{a}=-10.647$ dan koefisien regresi $\mathrm{b}=$ 0.994. Dengan demikian menghasilkan persamaan regresi sederhana $\hat{\mathrm{X}}_{2}=-10.647+$ $0.994 X_{1}$. Untuk mengetahui pengaruh langsung antar variabel maka dilakukan perhitungan koefisien jalur dengan bantuan aplikasi SPSS ver. 20. Hasil perhitungan dapat dilihat pada tabel 3 . berikut:

Tabel 3. Koefisien Jalur Value orientation $\left(X_{1}\right)$ terhadap Personality $\left(X_{2}\right)$

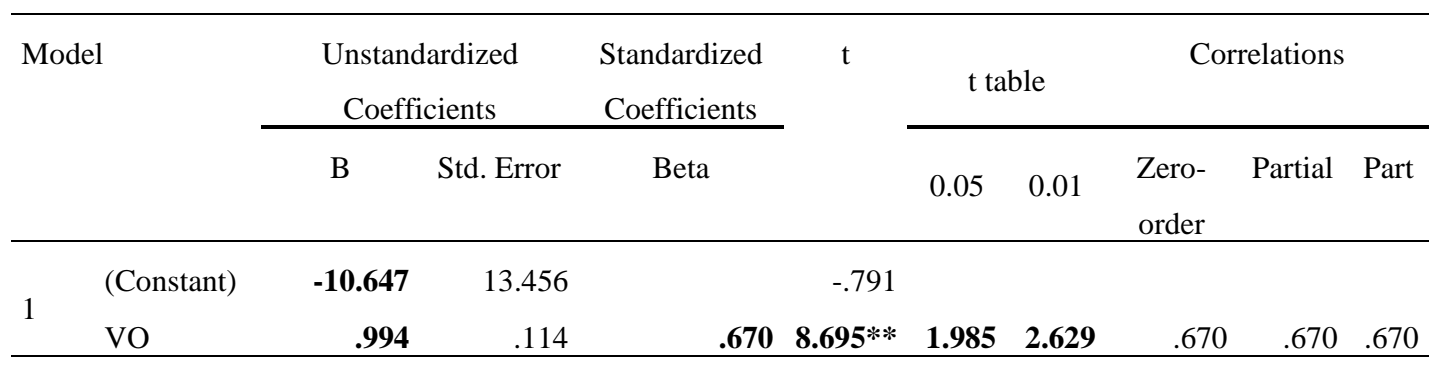

a. Endogenous Variable: Personality

$* * \mathrm{p}<0.01$

Hasil perhitungan phi 21 berdasarkan tabel 3 sebesar 0.670 dengan $t_{\text {hitung }}=8.695$ lebih besar dari tabel $(0.05 ; 93)=1.985$ yang artinya koefisien jalur $\mathrm{X}_{1}$ terhadap $\mathrm{X}_{2}$ signifikan pada $\alpha=0.05$. Dengan demikian terdapat pengaruh langsung antara value orientation terhadap personality.

Berdasarkan ketiga hasil perhitungan diatas maka dapat digambarkan model empirik seperti pada gambar dibawah ini:

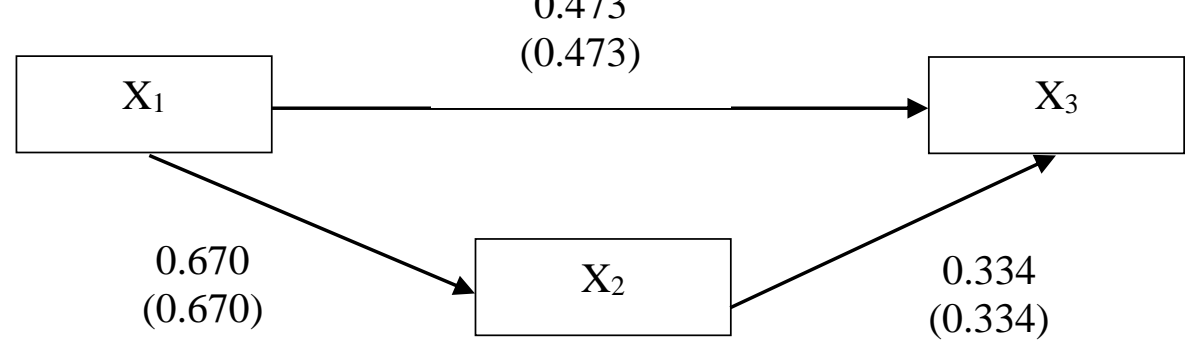

Gambar 3. Model Empirik Penelitian

Keterangan:

$\mathrm{X} 1$ : value orientation siswa

$\mathrm{X} 2$ : personality siswa.

$\mathrm{X} 3$ : new enviromental paradigm siswa 
Atas dasar model empirik pada gambar 2, maka diketahui besar koefisien jalur antara $\mathrm{X}_{1} \mathrm{X}_{2}$ dan $\mathrm{X}_{2} \mathrm{X}_{3}$ sebesar 0.670 dan 0.334 , hasil ini kemudian menjadi dasar penentuan pengaruh tidak langsung antara $X_{1}$ terhadap $X_{3}$ melalui $X_{2}$ sehingga diperoleh phi31.2 sebesar 0.224 , dan menghitung thitung, didapatkan $t_{\text {hitung }}=2.283$ lebih besar dari $\mathrm{t}_{\text {tabel }(0.05 ; 92)}=1.986$ yang berarti terdapat pengaruh tidak langsung $\mathrm{X}_{1}$ terhadap $\mathrm{X}_{3}$ melalui $\mathrm{X}_{2}$ yang signifikan pada $\alpha=0.05$. Oleh karena itu, dapat disimpulkan bahwa meningkatnya value orientation dapat meningkatkan new environmental paradigm secara langsung dan secara tidak langsung melalui meningkatnya personality.

Adapun berdasarkan hasil perhitungan dapat dirangkum hasil pengujian hipotesis pada tabel 4 berikut ini:

Tabel 4. Rangkuman Hasil Pengujian Hipotesis

\begin{tabular}{|c|c|c|c|}
\hline $\begin{array}{l}\text { Hipotesis } \\
\text { Statistika }\end{array}$ & Koefisien Jalur & thitung & $t_{\text {tabel }}$ \\
\hline $\begin{array}{l}\mathrm{H}_{0}: \mathrm{Phi}_{31}=0 \\
\mathrm{H}_{1}: \mathrm{Phi}_{31}>0\end{array}$ & 0.473 & $5.177^{*}$ & 1.985 \\
\hline $\begin{array}{l}\mathrm{H}_{0}: \mathrm{Phi}_{32}=0 \\
\mathrm{H}_{1}: \mathrm{Phi}_{32}>0\end{array}$ & 0.334 & $3.417 *$ & 1.985 \\
\hline $\begin{array}{l}\mathrm{H}_{0}: \mathrm{Phi}_{21}=0 \\
\mathrm{H}_{1}: \mathrm{Phi}_{21}>0\end{array}$ & 0.670 & $8.695^{*}$ & 1.985 \\
\hline $\begin{array}{l}\mathrm{H}_{0}: \mathrm{Phi}_{31.2}=0 \\
\mathrm{H}_{1}: \mathrm{Phi}_{31.2}>0\end{array}$ & 0.224 & $2.283^{*}$ & 1.986 \\
\hline
\end{tabular}

Hasil penelitian seperti yang terdapat pada tabel 4 sesuai dengan hipotesis yang ada. Value orientation berpengaruh secara langsung dan signifikan terhadap new environmental paradigm dan personality siswa. Lalu, personality berpengaruh langsung terhadap new environmental paradigm siswa secara signifikan. Pengaruh 
tidak langsung value orientation terhadap new environmental paradigm melalui personality siswa pun signifikan.

Stern dan kawan-kawannya dengan teori model VBN (Value-Belief-Norm) mengemukakan bahwa value orientation mempengaruhi pembentukan pedoman diri tentang lingkungan atau dikenal sebagai new environmental paradigm (Bronfman, Cisternas, López-Vázquez, Maza, \& Oyanedel, 2015). Teori tersebut menguatkan hasil penelitian yang mana value orientation berpengaruh secara langsung dan signifikan terhadap new environmental paradigm siswa. Value orientation yang dimiliki siswa berkontribusi dalam mengkonstruksikan hasil berpikir siswa menjadi sebuah paradigma dalam berinteraksi dan mengelola lingkungan.

New environmental paradigm berhasil terbentuk pada diri siswa karena siswa mempertimbangkan nilai-nilai yang diterima dan sesuai dalam kehidupan. Kean Boon Chua dan kawan-kawannya pada tahun 2016 juga memiliki hasil penelitian dimana nilai biospheric, altruistic, dan egoistic berpengaruh dan signifikan terhadap new environmental paradigm. Artinya, ketiga nilai yang merupakan dimensi dari value orientation memiliki pengaruh terhadap pembentukan new environmental paradigm siswa (Chua, Quoquab, Mohammad, \& Basiruddin, 2016).

Berdasarkan hasil penelitian, personality berpengaruh secara langsung dan signifikan terhadap new environmental paradigm siswa juga terdapat dalam hasil penelitian oleh I Made Putrawan dan Lisa Dwi Ningtyas (Putrawan \& Ningtyas, 2019). Setiap siswa memiliki personality berbeda-beda. Personality siswa menggambarkan pola berpikir, perasaan, dan tindakan yang khas dalam merespon situasi yang dialami, salah satunya tentang permasalahan lingkungan yang akhirnya bisa membentuk new environmental paradigm siswa. Keberagaman dari personality siswa akan memperlihatkan respon yang berbeda-beda terhadap keadaan lingkungan, baik dalam hal pemeliharaan, pengelolaan maupun pelestarian lingkungan.

Berdasarkan hasil penelitian, value orientation berpengaruh langsung terhadap personality siswa secara signifikan. Hasil tersebut dikuatkan oleh Lilach Sagiv, Shalom H. Schwartz, dan Ariel Knafo yang menyebutkan dalam penelitiannya bahwa nilai-nilai keyakinan dengan personality saling berpengaruh, karena pola 
karakteristik yang secara konsisten terbentuk dipengaruhi oleh nilai keyakinan yang dimiliki (Roccas, Sagiv, Schwartz, \& Knafo, 2002). Personality yang dimiliki siswa dapat mengarah kepada perilaku ramah lingkungan karena siswa memiliki landasan nilai-nilai berlingkungan. Hal-hal yang membentuk nilai berlingkungan tersebut kemungkinan karena program sekolah yang membiasakan siswa untuk hemat energi, hemat air, dan pengurangan sampah plastik.

Berdasarkan hasil penelitian, terdapat pengaruh tidak langsung value orientation terhadap new environmental paradigm melalui personality. Artinya, personality sebagai mediator yang baik antara value orientation dengan new environmental paradigm. Value orientation dalam membentuk new environmental paradigm tidak harus terjadi secara langsung, bisa saja dipengaruhi personality yang dimiliki siswa.

Value orientation dan personality dapat menjadi faktor yang menentukan new environmental paradigm siswa. Hal itu dikarenakan paradigma yang dijadikan pedoman diri dalam berinteraksi dengan lingkungan dapat terbentuk dalam diri siswa sesuai dengan nilai yang diyakini maupun kepribadian yang mengarah kepada lingkungan. Hasil penelitian yang didapat memberikan kontribusi teoritik dan memiliki subjek penelitian yang berbeda pada model Tai-Yi Yu dan Tai-Kuei Yu (2017) yang mana diketahui value orientation dan personality mempengaruhi new environmental paradigm dengan subjek yang diteliti ialah mahasiswa.

\section{KESIMPULAN}

Temuan dalam penelitian sebagai berikut : (1) Value orientation berpengaruh langsung terhadap new environmental paradigm secara signifikan; (2) Personality berpengaruh langsung terhadap new environmental paradigm secara signifikan; (3) Value orientation berpengaruh langsung terhadap personality secara signifikan; (4) Value orientation berpengaruh tidak langsung terhadap new environmental paradigm melalui personality secara signifikan. Berdasarkan temuan-temuan tersebut, dapat disimpulkan bahwa untuk mengurangi variasi new environmental paradigm maka faktor-faktor seperti value orientation dan personality perlu dipertimbangkan untuk diminimalkan pula variasinya 


\section{REFERENSI}

Abdullah, A., \& Marican, S. (2016). The Effects of Big-Five Personality Traits on Deviant Behavior. Procedia - Social and Behavioral Sciences, 219, 19-25.

Arcury, T. A., Johnson, T. P., \& Scollay, S. J. (1986). Ecological Worldview and Environmental Knowledge: The "New Environmental Paradigm." The Journal of Environmental Education, 17(4), 35-40.

Axelrod, L. (1994). Balancing Personal Needs with Environmental Preservation: Identifying the Values that Guide Decisions in Ecological Dilemmas. Journal of Social Issues, 50(3), 85-104.

Bernstein, J., \& Szuster, B. W. (2019). The new environmental paradigm scale: Reassessing the operationalization of contemporary environmentalism. Journal of Environmental Education, 50(2), 73-83.

Bronfman, N., Cisternas, P., López-Vázquez, E., Maza, C., \& Oyanedel, J. (2015). Understanding Attitudes and Pro-Environmental Behaviors in a Chilean Community. Sustainability, 7(10), 14133-14152.

Cervone, D., \& Pervin, L. A. (2010). Personality: Theory and Research.

Chua, K. B., Quoquab, F., Mohammad, J., \& Basiruddin, R. (2016). The Mediating Role of New Ecological Paradigm between Value Orientations and ProEnvironmental Personal Norm in The Agricultural Context. Asia Pacific Journal of Marketing and Logistics, 28(2), 323-349.

Dahriyanto, L. F., Rahmawati, D. A., \& Muhammad, A. H. (2018). Intensi Perilaku Pro-Konservasi Ditinjau dari Orientasi Nilai Individu Pada Mahasiswa Universitas Negeri Semarang. 10(2), 180-191.

Daikoban, D., Putrawan, I. M., \& S, D. V. (2019). " Students 'Personality in Environmental Model based on students 'Attitude, LOC and Personal Responsiblity ". 5013-5021. 


\section{IJEEM: Indonesian Journal of Environmental Education and Management e-ISSN: 2549-5798 \\ Vol.6 No. 2, 31 Juli 2021 \\ DOI : doi.org/10.21009/IJEEM.062.03}

De Groot, J. I. M., \& Steg, L. (2009). Mean or green: which values can promote stable pro-environmental behavior? Conservation Letters, 2(2), 61-66.

Dunlap, R. E. (2008). The New Environmental Paradigm Scale: From Marginality to Worldwide Use. The Journal of Environmental Education, 40(1), 3-18.

Han, J. H., \& Lee, E. (2016). The different roles of altruistic, biospheric, and egoistic value orientations in predicting customers' behavioral intentions toward green restaurants. International Journal of Tourism and Hospitality Research, 30(10), 71.

Kaan, S. A. U., Putrawan, I. M., \& Miarsyah, M. (2019). Hubungan antara Paradigma Lingkungan Baru dengan Perilaku Tanggung Jawab Lingkungan Siswa. Indonesian Journal of Environmental Education and Management, 4(1), $61-73$.

Leephaijaroen, S. (2016). Effects of the big-five personality traits and organizational commitments on organizational citizenship behavior of support staff at Ubon Ratchathani Rajabhat University, Thailand. Kasetsart Journal of Social Sciences, 37(2), 104-111.

Malisi, A. S., \& Nadiroh, N. (2017). Pengaruh Paradigma Lingkungan dan Personal Value terhadap Carbon Footprint Mahasiswa. Jurnal Green Growth dan Manajemen Lingkungan, 6(1), 25-32.

Matthews, N., \& Keys, P. (2019, September 9). Humans have caused this environmental crisis. It's time to change how we think about risk. World Economic Forum.

McShane, S. L., \& Glinow, M. A. Von. (2010). Organizationa Behavior. In Contexts. New York, NY: McGraw-Hill.

Mehta, M. D., \& Ouellet, E. (1995). Environmental Sociology: Theory and Practice.

Natasia, D., Azrai, E. P., \& Ernawati, E. (2015). Perbedaan Paradigma Lingkungan 
Baru (NEP) Mahasiswa Dengan Gaya Kognitif Field Independent Dan Field Dependent. BIOSFER, 8(2), 1-8.

O'Neill, Z. S. (2019). It's a crisis, not a change': the six Guardian language changes on climate matters. Guardian Climate Pledge 2019 Environment.

Putrawan, I. M. (2015). Measuring New Environmental Paradigm Based on Students' Knowledge About Ecosystem and Locus of Control. Eurasia Journal of Mathematics, Science and Technology Education, 11(2), 325-333.

Putrawan, I. M. (2017). Predicting Students' Responsible Environmental Behavior (REB) Based on Personality, Students' New Environmental Paradigm (NEP) and Naturalistic Intelligence. Advanced Science Letters, 23(9), 8586-8593.

Putrawan, I. M. (2018). Predicting Environmental Leadership Based on Personality and Its Construct Validity. International Journal of Engineering and Technology, 7(4), 92-95.

Putrawan, I. M. (2019). A Comparative Analysis of New Ecological Paradigm (NEP), Ecosystem Knowledge, and Students' Self-Control Based on Gender. International Journal of Innovative Technology and Exploring Engineering, $8(6), 68-71$.

Putrawan, I. M., \& Ningtyas, L. D. (2019). The Role of Environmental Leadership and Personality on VBN Model. Indian Journal of Public Health Research \& Development, 10(9), 1776.

Roccas, S., Sagiv, L., Schwartz, S. H., \& Knafo, A. (2002). The Big Five Personality Factors and Personal Values. Personality and Social Psychology Bulletin, 28(6), 789-801.

Sigit, D. V., Ernawati, E., \& Qibtiah, M. (2017). Hubungan Pengetahuan Lingkungan Hidup Dengan Kemampuan Pemecahan Masalah Pencemaran Lingkungan Pada Siswa Sman 6 Tangerang. Biosfer: Jurnal Pendidikan 
Biologi, 10(2), 1-6.

Stern, P. C. (2000). Toward a Coherent Theory of Environmentally Significant Behavior. Journal of Social Issues, 56(3), 407-424.

Thomson, J. (2013). New Ecological Paradigm Survey 2008: Analysis of the NEP results. In Waikato Regional Council Technical Report.

University of East Anglia. (2019, September 19). Investments to address climate change are good business. Science Daily.

Wright, C. I., Williams, D., Feczko, E., Barrett, L. F., Dickerson, B. C., Schwartz, C. E., \& Wedig, M. M. (2005). Neuroanatomical Correlates of Extraversion and Neuroticism. Cerebral Cortex, 16(12), 1809-1819.

Yu, T.-Y., \& Yu, T.-K. (2017). The Moderating Effects of Students' Personality Traits on Pro-Environmental Behavioral Intentions in Response to Climate Change. International Journal of Environmental Research and Public Health, 14(12), 1472. 